\title{
DETERMINAN FEE AUDIT PADA KAP DI JAWA TIMUR
}

\author{
Kholilah \\ Fakultas Ekonomi UIN Maulana Malik Ibrahim Malang \\ Jl Gajayana 50 Malang \\ kholilahak@yahoo.co.id
}

\section{Abstract}

This study sets out to examine factors influencing audit fees paid on public accountant firm (KAP) in East Java. Data were collected from 2012 company annual reports audited by KAP. An audit fee models using a sample of 84 audited financial reports by using multiple linear regression analysis. The findings show a direct relationship between audit fees and each of corporate size and audit location, an inverse relationship has been detected between audit fees and each of audit risk and seasonality, the findings also revealed that audit fees are not significantly influenced by KAP switching.

Keywords: audit fees, East Java, corporate size, audit risk, seasonality, KAP switching, audit location

Hoesada (2009) menyampaikan di tahun 2008, profil dunia usaha Indonesia terdiri dari 124.000 unit usaha koperasi, 31,06 juta unit usaha mikro, 10,65 juta unit usaha kecil, 2,92 juta unit usaha menengah, 2.000 unit usaha besar, dan 345 unit usaha perusahaan publik, dengan asumsi sampai tahun 2012 jumlah perusahaan tersebut tetap maka secara kuantitas pangsa pasar audit sangat besar. Apabila dibandingkan dengan jumlah KAP di Indonesia berdasarkan directory IAPI (2011) yaitu 504 kantor (404 kantor pusat dan 100 kantor cabang) yang terletak di lima koordinator wilayah yaitu Jakarta, Semarang, Indonesia Timur, Medan, Padang dan Palembang. Secara hitungan matematis jumlah pasar jasa audit masih sangat 
luas, namun dalam prakteknya terdapat persaingan ketat antar KAP dalam memperoleh klien (Ludigdo, 2005:81). Ketatnya persaingan KAP juga menimbulkan adanya perang fee di kalangan akuntan publik (Akuntanonline: 2012a), bahkan kementerian keuangan "pasrah" dengan adanya praktek ini (Akuntanonline: 2012b).

Tidak ada yang salah dengan manajemen mencoba mendapatkan jasa audit dengan biaya yang lebih rendah atau auditor menawarkan jasa mereka dengan harga yang lebih rendah dibandingkan KAP lainnya. Namun ada hal penting yang harus diperhatikan oleh auditor yaitu bahwa kompetisi berdasarkan harga ini tidak akan memicu dilakukannya pengauditan dengan kualitas yang lebih rendah atau bahkan membatasi independensi auditor. Selain itu yang perlu diingat juga adalah bahwa praktek lowballing yaitu auditor menetapkan fee yang rendah dengan tujuan untuk memenangkan kontrak dan berharap menutup imbalan jasa audit awal dengan memberikan jasa lainnya kepada klien atau dengan cara menaikkan imbalan jasa auditnya di periode mendatang dilarang oleh kode etik profesi subbagian 290.210 290.212 .

Fungsi profesi akuntan publik yaitu sebagai pihak penyaksi atau fungsi atestasi terhadap laporan keuangan manajemen (Harahap, 2002) sebenarnya sangat mulia dan dibutuhkan oleh masyarakat. Oleh karenanya profesi ini harus dilindungi dan diawasi agar tetap dapat menjaga kepentingan masyarakat. Secara tidak tertulis peranan profesi ini seakan sudah termasuk dalam contract social yang berarti bahwa profesi ini dikontrak oleh masyarakat untuk menjadi aktor dalam melindungi kepentingan masyarakat dalam menggunakan informasi keuangan yang dapat digunakan untuk pengambilan keputusan. Oleh sebab itu, penelitian mengenai faktorfaktor yang mempengaruhi penetapan fee audit perlu dilakukan, mengingat pentingnya profesi ini dalam masyarakat, sehingga secara tidak langsung masyarakat atau khalayak memahami apa yang menjadi dasar penetapan fee audit guna menjaga kualitas audit yang dilakukan. Perbedaan penelitian mengenai determinan fee audit antara satu negara dengan negara yang lain adalah ketersediaan data (Naser dan Nuseibeh: 2007).

Faktor-faktor yang mempengaruhi penetapan fee audit telah dikembangkan oleh Simunic (1980), yang oleh beberapa peneliti disebut sebagai faktor-faktor tradisional (Caneghem, 2010; dan Besacier \& Schatt, 2007). Faktor-faktor tersebut adalah ukuran perusahaan, risiko audit, dan kompleksitas audit. Penggunaan total aset sebagai ukuran perusahaan mempengaruhi variabel kompleksitas yang diukur menggunakan perbandingan antara aset lancar dengan total aset atau persediaan dengan total aset (Naser \& Nuseibeh: 2007), oleh karena itu penelitian ini tidak menggunakan kompleksitas audit sebagai determinan fee audit. Faktor tradisional yang digunakan dalam penelitian ini adalah ukuran perusahaan dan risiko audit.

Ukuran perusahaan merupakan variabel yang paling banyak digunakan dalam penentuan fee audit (Naser \& Nuseibeh, 2007; Chan, Ezzamel, \& Gwilliam, 1993; Taylor, 2011; dan Ellis \& Booker, 2011). Perbedaan antara satu penelitian dengan 
penelitian yang lain hanya pada pengukuran ukuran perusahaan (Chan, et al., 1993 dan Naser \& Nuesibeh, 2007). Semakin besar ukuran perusahaan, maka semakin kompleks transaksi yang dimiliki oleh perusahaan tersebut, sebagai akibatnya auditor akan membutuhkan semakin banyak waktu untuk melakukan pemeriksaan. Pengukuran ukuran perusahaan yang paling tepat digunakan dalam penelitian yang berbasis laporan keuangan adalah total aset (Chan, et al., 1993 dan Naser \& Nuesibeh, 2007).

Risiko audit menjadi faktor yang penting dalam menentukan fee audit setelah kebangkrutan Enron dan Worldcom yang diikuti dengan kasus hukum yang dialami KAP yang mengaudit kedua perusahaan tersebut (Naser \& Nuseibeh: 2007). Meskipun demikian pengukuran risiko bisnis klien (salah satu penentu risiko audit) bukanlah hal yang mudah, hal ini disebabkan oleh konstruk multidimensional dari risiko bisnis klien (Stanley: 2011). Salah satu pengukuran yang bisa digunakan dalam menentukan risiko audit adalah leverage (Stanley: 2011). Peningkatan leverage berbanding lurus dengan peningkatan biaya monitoring oleh kreditor sehingga risiko bisnis klien bisa ditekan sebagai dampaknya akan terjadi pengurangan fee audit. Naser dan Nuseibeh (2007) serta Joshi dan Al-Bastaki (2000) menemukan pengaruh positif fee audit dan leverage. Sedangkan, Chan et. al (1993), Canegem (2010), Fachriyah (2008) dan Taylor \& Simon (1999) tidak berhasil menemukan pengaruh signifikan variabel ini terhadap fee audit.

Variabel lain yang diduga berpengaruh terhadap fee audit adalah waktu audit, pergantian KAP, dan lokasi audit. Audit yang dilakukan pada busy seasons menghasilkan penetapan fee audit yang lebih tinggi dibandingkan audit yang dilakukan pada periode selain busy seasons (Ellis \& Booker: 2011). Busy season atau peak season dalam kalangan praktiksi akuntan publik adalah bulan Januari-April (Ellis \& Booker: 2011). Seperangkat aturan telah mengikat entitas di Indonesia untuk menjadikan 31 Desember sebagai akhir periode pelaporan, oleh karena itu bulan Januari-April dikenal sebagai busy season bagi auditor, sehingga pengukuran waktu audit dalam penelitian ini adalah akhir periode pelaporan keuangan. Francis \& Wang (2005), Hay, et al. (2006), Griffint \& Lont (2007) serta Taylor (2011) menemukan pengaruh positif variabel waktu audit terhadap fee audit. Berbeda dengan keempat peneliti tersebut Chan, et al. (1993), Peel \& Roberts (2003), Besacier \& Schatt (2007), Caneghem (2010), dan Stanley (2011) tidak berhasil menemukan pengaruh variabel ini terhadap fee audit.

PMK Nomor 17/PMK.01/2008 tentang Jasa Akuntan Publik mengatur kewajiban untuk melakukan pergantian KAP. Perubahan peraturan ini menyatakan bahwa pemberian jasa audit umum atas laporan keuangan dari suatu entitas dapat dilakukan paling lama 6 (enam) tahun buku berturut-turut oleh KAP yang sama dan 3 (tiga) tahun berturut-turut oleh auditor yang sama kepada satu klien yang sama (pasal 3 ayat 1). Peraturan ini secara tidak langsung mewajibkan KAP untuk melakukan rotasi dalam penugasan audit (Maradona: 2009). Hoyle (1978) dan 
Raiborn \& Massoud (2006) menemukan pengaruh positif variabel pergantian KAP terhadap fee audit, karena pada awal perikatan auditor memerlukan studi yang komprehensif mengenai karakteristik perusahaan, data-data historis, sistem pengendalian internal dan sistem keuangan. Berbeda dengan kedua peneliti ini Peel \& Roberts (2003), tidak berhasil menemukan pengaruh variabel pergantian KAP terhadap fee audit.

Jawa Timur merupakan provinsi dengan pertumbuhan ekonomi tertinggi di Indonesia (Sasongko: 2013), tingginya pertumbuhan ekonomi di provinsi Jawa Timur membuat peneliti tertarik untuk mengetahui pengaruh lokasi audit yang dilakukan di Jawa Timur dengan lokasi lain di luar Jawa Timur. Hal ini didasarkan pada hasil penelitian Taylor (2011) yang menyebutkan bahwa daerah-daerah yang mendominasi perekonomian negara menghasilkan penetapan fee audit yang berbeda. Chan, et al. (1993) dan Peel \& Roberts (2003) menemukan pengaruh positif variabel lokasi audit terhadap fee audit, berbeda dengan keduanya Taylor (2011) menemukan bahwa terdapat pengaruh negatif variabel lokasi audit terhadap fee audit.

Ketidakkonsistenan beberapa hasil penelitian tentang determinan fee audit membuka peluang bagi peneliti untuk menguji kembali faktor-faktor yang berpengaruh terhadap fee audit terutama untuk variabel risiko perusahaan, waktu audit, pergantian KAP, dan lokasi audit, sedangkan variabel ukuran perusahaan peneliti ambil karena variabel ini merupakan variabel yang menghasilkan pengaruh paling signifikan terhadap fee audit hampir di semua penelitian mengenai determinan fee audit. Selain itu, Penelitian ini merupakan pengembangan dari penelitian yang dilakukan oleh Peel \& Roberts (2003) serta Taylor (2011) dengan menggunakan leverage sebagai pengukuran risiko audit seperti yang dilakukan oleh Naser dan Nuseibeh (2007), dan Joshi dan Al-Bastaki (2000).

Berdasarkan uraian di atas, maka masalah dalam penelitian ini dapat dirumuskan sebagai berikut: 1) Apakah ukuran perusahaan berpengaruh terhadap fee audit? 2) Apakah risiko audit berpengaruh terhadap fee audit? 3) Apakah waktu audit berpengaruh terhadap fee audit? 4) Apakah pergantian KAP berpengaruh terhadap fee audit? 5) Apakah lokasi audit berpengaruh terhadap fee audit?

\section{Telaah Literatur}

\section{Ukuran Perusahaan}

Indonesia adalah negara dengan perlindungan investor yang lemah sehingga kemungkinan terjadi masalah keagenan tinggi (La Porta, et al., 2000). Jensen \& Meckling (1986) mengatakan masalah keagenan (agency problem) menyebabkan ketidakadilan bagi pemegang saham minoritas dan kreditur, agent cenderung memaksimalkan return jangka pendek daripada jangka panjang (Dechow \& Sloan, 1991), menanamkan investasi pada proyek yang tidak menguntungkan untuk meningkatkan ukuran perusahaan, dan meningkatkan kompensasi (Jensen, 1986). 
Pentingnya profesi auditor dalam menjembatani adanya perbedaan kepentingan antara invenstor dan manajemen berkaitan dengan adanya kemungkinan kerugian keuangan yang dialami perusahaan (Ming \& Dolley, 2009). Salah satu faktor yang mempengaruhi tingginya permintaan jasa audit untuk mengurangi adanya kerugian keuangan yang dialami perusahaan adalah ukuran perusahaan (Ming \& Dolley, 2009).

Ukuran perusahaan (Client Size) adalah salah satu variabel yang menghasilkan pengaruh paling signifikan dan konsisten terhadap penentuan fee audit. Pengukuran ukuran perusahaan sangat bervariatif, namun yang paling banyak digunakan adalah total aset (Hay, et al., 2006). Total aset terdiri dari aset lancar dan aset tetap. Semakin besar aset dibutuhkan pengawasan yang semakin intensif dan tepat sasaran atas penggunaan sumberdaya oleh manajemen perusahaan sehingga dibutuhkan jaminan dari pihak independen bahwa manajemen perusahaan tidak melakukan tindakan yang memungkinkan pihak prinsipal mengalami kerugian di masa yang akan datang.

Beberapa penelitian yang berhasil menemukan pengaruh positif total aset terhadap fee audit diantaranya adalah di Australia (Taylor, 2011 dan Jubb, et al, 1996), Inggris (Chan, et al., 1993 dan Peel \& Roberts, 2011), Perancis (Besacier $\&$ Schatt, 2007), dan di Selandia Baru (Firth, 1985). Taylor \& Simon (1999) secara khusus membahas mengenai penelitian tentang determinan fee audit yang telah dilakukan di 20 negara pada tahun 1991-1995 hasil penelitiannya menunujukkan bahwa di 20 negara tersebut total aset berpengaruh positif terhadap fee audit. Berdasarkan uraian mengenai ukuran perusahaan dan pengaruhnya terhadap fee audit, maka dapat dibuat rumusan hipotesis sebagai berikut:

$\mathrm{H}_{1}$ : Ukuran perusahaan berpengaruh positif terhadap fee audit.

\section{Risiko Audit}

Agency theory menjelaskan bahwa perusahaan adalah kumpulan kepentingan antara agent dan principal. Teori tersebut juga menyebutkan bahwa salah satu cara untuk mengurangi kerugian perusahaan yang dikelola oleh agent adalah melakukan proses verifikasi laporan keuangan oleh auditor independen (Ming dan Dolley: 2009). Dalam proses verifikasi tersebut auditor menghadapi risiko yang disebut dengan risiko audit. Risiko audit (audit risk) merupakan faktor yang cukup penting untuk menentukan besarnya fee audit karena meningkatnya jumlah kegagalan audit dapat menyebabkan tuntutan terhadap auditor (Karim dan Moizer, 1996). Risiko audit bisa diukur dengan tingginya utang perusahaan (Ming dan Dolley, 2009).

Rasio leverage menunjukkan seberapa besar perusahaan menggunakan utang dari luar untuk membiayai operasi maupun ekspansi perusahaan. Rasio leverage yang digunakan dalam penelitian ini adalah debt ratio atau perbandingkan antara total utang dengan total aset. Semakin rendah rasio utang, semakin bagus kondisi 
perusahaan sebab, hanya sebagian kecil aset perusahaan yang dibiayai dengan utang, selain itu menurut Guney, et al., dalam Wijaya, Bandi, dan Hartoko (2010) perusahaan dengan leverage tinggi memiliki kecenderungan financial constraint yang tinggi karena perusahaan dihadapkan pada biaya pendanaan eksternal yang tinggi pula.

Naser dan Nuseibeh (2007) berhasil menemukan pengaruh positif leverage terhadap fee audit. Hal ini disebabkan oleh budaya perbankan di Jordania yang cenderung memberikan pinjaman pada perusahaan yang memang kredibel untuk menghindari risiko kegagalan bayar nasabah. Senada dengan Naser dan Nuseibeh (2007), Joshi dan Al-Bastaki (2000) menemukan adanya pengaruh positif antara fee audit dan leverage di Bahrain. Berdasarkan uraian mengenai risiko audit dan pengaruhnya terhadap fee audit maka, dapat dibuat rumusan hipotesis sebagai berikut:

$\mathrm{H}_{2}$ : Risiko audit berpengaruh positif terhadap fee audit.

\section{Waktu Audit}

PSAK 1 mengenai penyajian laporan keuangan paragraf 34 tentang frekuensi pelaporan tidak secara eksplisit menerangkan tanggal atau bulan pelaporan keuangan oleh sebuah entitas, namun tanggal pelaporan keuangan yang umum digunakan di Indonesia adalah tanggal 31 Desember. Oleh karena itu bulan Januari - April sering dikenal sebagai bulan sibuk (busy seasons) bagi auditor. Jadwal pengerjaan audit yang ketat dan pembagian tim yang tepat diperlukan untuk menyelesaikan laporan audit tepat waktu sehingga bisa digunakan oleh para pihak yang berkepentingan terhadap laporan keuangan.

Chan, et al. (1993) menyebutkan bahwa terdapat perbedaan kinerja auditor pada periode busy season dan non-busy season, hal ini menunjukkan adanya perbedaan penetapan fee audit diantara kedua periode tersebut (Karim \& Moizer, 1996). Pengukuran waktu audit (seasonality) yang umum digunakan adalah periode pelaporan keuangan yaitu 31 Desember seperti yang dilakukan oleh Griffint \& Lont (2007). Beberapa penelitian yang berhasil menemukan pengaruh positif waktu audit terhadap fee audit adalah Francis \& Wang (2005), Hay, et al. (2006), Griffint \& Lont (2007), serta Taylor (2011) berhasil menemukan pengaruh positif waktu audit terhadap fee audit. Berdasarkan uraian mengenai waktu audit dan pengaruhnya terhadap fee audit maka, dapat dibuat rumusan hipotesis sebagai berikut:

$\mathrm{H}_{3}$ : Waktu audit berpengaruh positif terhadap fee audit.

\section{Pergantian KAP}

Perbedaan kepentingan antara agen dan prinsipal berhubungan dengan agency cost yang dapat dikurangi dengan pengawasan oleh investor (Peel dan Roberts: 2003), aktivitas pengawasan melibatkan auditor independen untuk memverifikasi 
informasi akuntansi yang disiapkan oleh agen kepada prinsipal. Terdapat perbedaan kualitas audit antara satu KAP dengan KAP yang lain, De Angelo (1981) menyebutkan bahwa KAP yang besar akan cenderung menyajikan kualitas audit yang lebih tinggi dibandingkan KAP kecil. Menurut Deis \& Giroux (1992) besar kecilnya KAP dapat dilihat dari penetapan fee audit dalam usaha mempertahankan kliennya untuk tidak berpindah pada KAP yang lain. Hoyle (1978) serta Raiborn dan Massoud (2006) menemukan pengaruh positif pergantian KAP terhadap fee audit, karena pada awal perikatan auditor memerlukan studi yang komprehensif mengenai karakteristik perusahaan, data-data historis, sistem pengendalian internal dan sistem keuangan. Berdasarkan uraian mengenai pergantian auditor dan pengaruhnya terhadap fee audit maka, dapat dibuat rumusan hipotesis sebagai berikut:

$\mathrm{H}_{4}$ : Pergantian KAP berpengaruh positif terhadap fee audit.

\section{Lokasi Audit}

Salah satu faktor yang dapat menyebabkan terjadinya perbedaan harga yang dalam penelitian ini adalah fee menurut Tarigan (2012:137) adalah jarak, jarak mempengaruhi tingkat aksesibilitas sebuah lokasi. Tingkat aksesibilitas merupakan tingkat kemudahan dalam mencapai dan menuju arah suatu lokasi ditinjau dari lokasi lain di sekitarnya (Tarigan, 2012: 122). Chan, et al. (1993) melakukan penelitian mengenai pengaruh lokasi audit terhadap fee audit. Hasil penelitiannya menemukan bahwa di Inggris lokasi audit berpengaruh positif terhadap fee audit. Chan, et al. (1993) mengungkapkan bahwa hasil penelitiannya konsisten dengan hasil wawancara yang dilakukan dengan salah satu partner di London yaitu bahwa ada perbedaan fee antara penugasan audit yang dilakukan di London dan di Luar London. Peel dan Roberts (2003) melakukan pengembangan dari penelitian Chan, et al. (1993) dan hasil penelitiannya juga menemukan pengaruh positif dari lokasi audit yang dilakukan di London dan di Luar London terhadap fee audit. Berdasarkan uraian mengenai lokasi audit dan pengaruhnya terhadap fee audit maka, dapat dibuat rumusan hipotesis sebagai berikut:

$\mathrm{H}_{5}$ : Lokasi audit berpengaruh positif terhadap fee audit.

\section{Metode Penelitian}

Penelitian ini menggunakan pendekatan kuantitatif karena berusaha menjelaskan hubungan antara variabel penelitian melalui pengujian hipotesis dan secara umum data disajikan dalam bentuk angka dan dihitung melalui uji statistik. Populasi studi ini adalah seluruh penugasan audit atas klien-klien KAP di Jawa Timur selama tahun 2012. Perikatan tersebut meliputi penugasan untuk pemeriksaan laporan keuangan tahun 2011 ataupun tahun-tahun sebelumnya. Dipilihnya KAP di Jawa Timur dalam penelitian ini didasarkan pada lokasi yang berdekatan dengan peneliti, dan 
adanya keterbatasan waktu serta biaya dari pihak peneliti menjadi pertimbangan dalam pemilihan lokasi.

Teknik pengambilan sampel yang digunakan dalam penelitian ini adalah teknik pengambilan sampel nonprobabilitas dengan metode convenience sampling atau pengambilan sampel yang mudah untuk mengambil sampling. Metode ini digunakan karena penyebaran kuesioner bersamaan dengan tenggat waktu penerbitan laporan keuangan dan pelaporan pajak, sehingga peneliti harus mencari KAP yang benarbenar bersedia mengisi kuesioner.

Teknik pengumpulan data menggunakan metode survei. Studi ini menggunakan mail survei. Berdasarkan Directory KAP dan AP (2011) jumlah KAP di Jawa Timur adalah 52 KAP yang terdiri dari 42 KAP di kota Surabaya dan 7 KAP di kota Malang. Selain itu, di kota Malang juga terdapat 2 KAP yang tidak terdaftar dalam directory KAP dan AP tersebut, hal ini disebabkan pada kedua KAP tersebut tidak terdapat partner yang bisa menandatangani opini, sehingga proses penerbitan opini merupakan tanggung jawab kantor pusat ataupun kantor cabang. Format kuesioner yang peneliti kembangkan merupakan format penjaring data oleh karena itu peneliti tidak harus dan memang tidak dapat dilakukan uji validitas dan reliabilitas datanya (Danim, 2007: 194). Peneliti hanya dituntut untuk berpikir logis dan cermat agar instrumen memenuhi syarat untuk menjawab permasalahan penelitian.

Variabel yang digunakan dalam penelitian ini adalah variabel dependen yaitu fee audit dan variabel independen yang terdiri dari ukuran perusahaan, risiko audit, waktu audit, pergantian KAP, dan lokasi audit yang diuji dalam satu model analisis. Pengukuran masing-masing variabel tersebut adalah fee audit (logaritma natural dari fee audit), ukuran perusahaan (logaritma natural dari total aset), waktu audit (Periode pelaporan keuangan 31 Desember $=1$, periode selain 31 Desember 0), pergantian KAP (terdapat pergantian KAP $=1$, tidak terdapat 0), lokasi audit (Jawa Timur $=1$, selain Jawa Timur 0).

Analisa data adalah cara-cara mengolah data yang telah terkumpul untuk kemudian dapat memberikan interpretasi. Hasil pengolahan data ini digunakan untuk menjawab masalah yang telah dirumuskan. Model estimasi yang digunakan untuk membentuk persamaan regresi menggunakan metode ordinary least square (OLS), sedangkan jenis persamaan regresi yang digunakan untuk menguji hipotesis penelitian adalah Multiple Regression (uji regresi linear berganda) karena peneliti menggunakan lebih dari satu variabel independen. Pengujian dilakukan dengan menggunakan uji regresi linear berganda dengan bantuan SPSS 16. Model dalam penelitian ini dapat digambarkan dalam gambar 1 . berikut ini: 


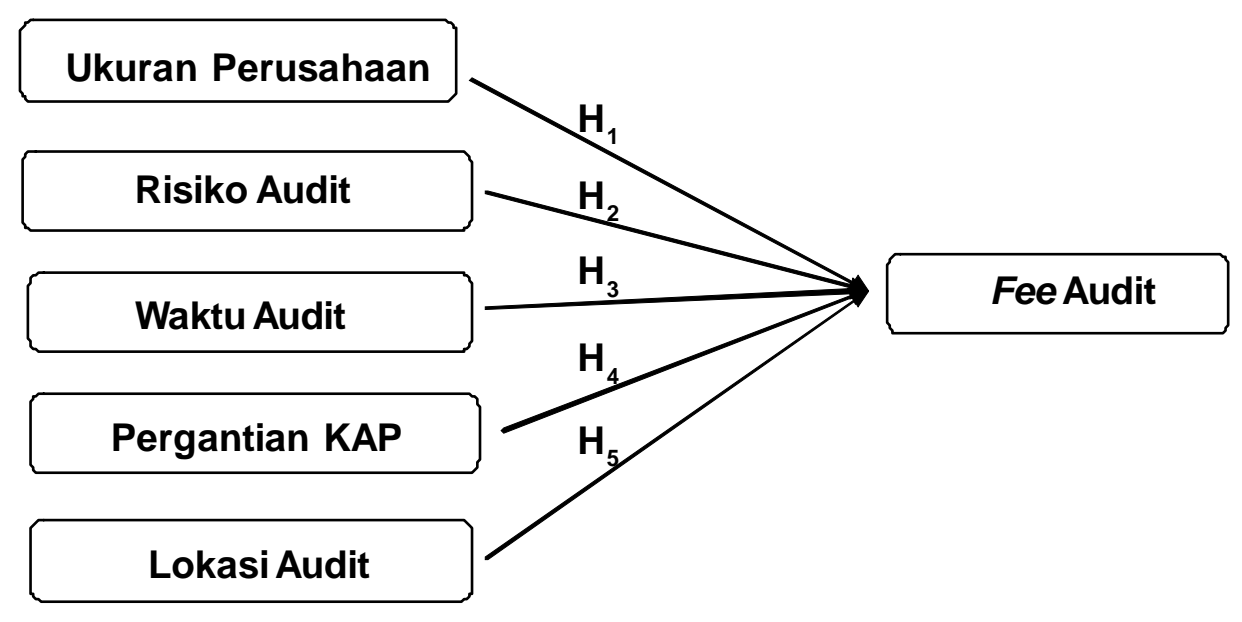

Gambar 1. Hipotesis Penelitian

Berdasarakan model penelitian diatas dapat dirumuskan dalam persamaan penelitian sebagai berikut:

$L n F E E=\beta_{0}+\beta_{1}$ LnSIZE $+\beta_{2}$ RISK $+\beta_{3}$ TIME $+\beta_{4}$ KAPCHANGE $+\beta_{5}$ LOCATION $+\mathrm{e}$

\section{Keterangan:}

LnFEE

LnSIZE

: Logaritma natural fee Audit

RISK

: Logaritma natural dari total aset

TIME

: Risiko Audit

KAPCHANGE : Pergantian KAP

LOCATION : Lokasi Audit

$\beta \quad$ :Intercept (Konstanta)

e : Error

\section{Analisis Statistik Deskriptif}

Statistik deskriptif merupakan statistik yang berfungsi untuk mengumpulkan, mengolah, menyajikan dan menganilisis data kuantitatif secara deskriptif. Secara khusus, statistik deskriptif digunakan untuk menunjukkan jumlah data dan menunjukkan nilai maksimum, nilai minimum, niali rata-rata dan nilai standar deviasi dari masing-masing variabel yang digunakan dalam penelitian. Hasil pengujian statistik deskriptif untuk penelitian ini disajikan pada tabel 1 . 
Tabel 1. Analisis Statistik Deskriptif

\begin{tabular}{lcccc}
\hline \multicolumn{1}{c}{ Variabel } & Minimum & Maksimum & Mean & Standar Deviasi \\
\hline RISK & 0 & 159 & 51.18 & 31.267 \\
TIME & 0 & 1 & $42,5 \%$ & - \\
KAPCHANGE & 0 & 1 & $47,6 \%$ & - \\
LOCATION & 0 & 1 & $41,7 \%$ & - \\
LnSIZE & 21.13 & 27.15 & 24.0436 & 1.18915 \\
LnFEE & 15.89 & 18.26 & 16.6636 & .65303 \\
\hline
\end{tabular}

Sumber: Data diolah, 2013

Jumlah sampel (N) dalam penelitian ini adalah 84 penugasan audit untuk tahun 2012 di KAP Jawa Timur. Nilai standar deviasi yang lebih kecil dari nilai rata-rata menunjukkan bahwa variabel LnFEE, LnSIZE, dan Risk memiliki perbedaan yang relatif kecil antara masing-masing perusahaan.

\section{Analisis Asumsi Klasik}

Pengujian hipotesis dalam penelitian ini menggunakan metode OLS yang terikat dengan sejumlah asumsi agar taksiran parameter memliki sifat Best Linier Unbias Estimator (BLUE). Asumsi yang digunakan dalam penelitian ini adalah uji normalitas, uji heterokedastisitas dan uji multikoleniaritas. Penelitian ini menggunakan data antar ruang (cross sectional data) sehingga tidak dilakukan uji autokorelasi karena autokorelasi sering ditemukan pada data runtut waktu (time series data), yaitu gangguan pada individu atau kelompok yang sama pada periode berikutnya (Ghozali, 2009:100).

Uji normalitas data dilakukan untuk mengetahui apakah dalam model regresi data variabel dependen dan independen berdistribusi normal. Model regresi yang baik adalah distribusi data normal. Cara yang digunakan untuk pengujian normalitas data dalam penelitian ini adalah data histogram, yang menunjukkan bahwa kurva dependen dan regression standardized residual membentuk gambar seperti lonceng atau mendekati kurva normal. Data residual dapat dikategorikan sebagai data normal dengan rata-rata sebesar 0 dan standar deviasi 1. Model berdistribusi normal karena rata-rata untuk residual diperoleh sebesar $1,93 \times 10^{-15}$ dengan standar deviasi sebesar 0,969.

Model regresi yang baik adalah tidak terjadi heterokedastisitas. Uji heterokedastisitas dalam penelitian ini menggunakan metode glesjer. Metode ini dilakukan dengan meregresikan semua variabel bebas terhadap nilai mutlak residualnya. Gejala heterokedastisitas ditunjukkan oleh koefisien regresi dari masing-masing variabel 
bebas terhadap nilai absolut residualnya. Berdasarkan pengujian yang dilakukan tidak terjadi gejala heterokedastisitas. Hal ini bisa dilihat dari tingkat signifikan masing-masing variabel yang lebih besar dari $1 \%$.

Model regresi yang baik seharusnya tidak terjadi korelasi diantara variabel independen. Uji multikolinieritas dalam penelitian ini menggunakan 2 cara yaitu melihat VIF dan nilai tolerance. Angka VIF dalam pengujian ini berkisar antara 1,082-1,767 dan angka tolerance berkisar antara 0,566-0,924. Dengan kata lain masing-masing variabel bebas menunjukkan nilai VIF $\leq 10$ dan nilai tolerance $\geq$ 0,10 sehingga dapat disimpulkan bahwa antar variabel bebas tidak terjadi multikolinieritas.

\section{Hasil Pengujian Hipotesis}

Uji hipotesis dalam penelitian ini menggunakan nilai koefisien determinasi yang disesuaikan (adjusted $R^{2}$ ), nilai statistik F, dan nilai statistik t. Hasil pengujian hipotesis menggunakan ketiga alat analisis tersebut, dijelaskan di bawah ini:

Tabel 2. Hasil Analisis Regresi (Uji F)

\begin{tabular}{cccc}
\hline F & R Square & Adjusted R Square & Sig \\
\hline 6.621 & 0,298 & 0,253 & 0.000 \\
\hline
\end{tabular}

Sumber: Data diolah, 2013

Berdasarkan tabel 2, besarnya kontribusi dari variabel bebas secara simultan terhadap variabel terikat berdasarkan hasil perhitungan dengan nilai koefisien determinasi yang disesuaikan (adjusted $R^{2}$ ) adalah sebesar 0,253. Hasil tersebut menjelaskan sumbangan atau kontribusi dari variabel bebas dalam model regresi yang digunakan terhadap variabel terikat adalah sebesar $25,3 \%$, sedangkan $74,7 \%$ disumbangkan oleh variabel lain di luar model. Berdasarkan tabel tersebut tingkat signifikan persamaan regresi dalam penelitian ini adalah sebesar 0,000 atau kurang dari $1 \%$. Hasil tersebut menunjukkan bahwa terdapat pengaruh yang signfikan secara simultan (bersama-sama) antara variabel ukuran perusahaan, risiko audit, waktu audit, pergantian KAP, dan lokasi audit terhadap fee audit.

Uji t digunakan untuk mengetahui pengaruh masing-masing variabel independen terhadap variabel dependen (Ghozali, 2009:88). Adapun hasil uji t dalam penelitian ini dapat dilihat pada tabel 3 berikut ini: 
Tabel 3. Uji t

\begin{tabular}{lcc}
\hline \multicolumn{1}{c}{ Variabel } & T & Sig. \\
\hline LnSIZE & 3,802 & 0,000 \\
RISK & $-2,754$ & 0,007 \\
TIME & $-3,303$ & 0,001 \\
KAPCHANGE & 0,742 & 0,461 \\
LOCATION & 3,234 & 0,002 \\
\hline
\end{tabular}

Sumber: data diolah, 2013

Dari tabel diatas dapat dijelaskan bahwa:

\section{Hipotesis 1}

Hipotesis 1 dinyatakan bahwa variabel ukuran perusahaan (LnSize) berpengaruh positif terhadap fee audit. Dari tabel 3 dapat dilihat bahwa nilai t hitung sebesar 3,802 dengan signifikansi alfa sebesar $0,000<0,01$ sehingga faktor ukuran perusahaan berpengaruh positif terhadap fee audit $(\mathrm{LnFee})$. Hal ini berarti semakin besar ukuran perusahaan maka fee audit yang dibebankan auditor terhadap klien semakin tinggi. Berdasarkan hasil tersebut maka Hipotesis 1 diterima. Hasil ini sesuai dengan hasil penelitian Taylor (2011), Jubb et. al, (1996), Chan, et al. (1993), Peel \& Roberts (2011), Besacier \& Schatt (2007), Firth (1985), dan Taylor \& Simon (1999).

Berpengaruhnya variabel ukuran perusahaan terhadap fee audit dikarenakan auditor yang melakukan audit di perusahaan besar akan menghabiskan lebih banyak waktu dan sumber daya untuk meninjau operasi klien karena perusahaan besar terlibat dalam sejumlah besar transaksi yang membutuhkan waktu berjam-jam bagi auditor untuk melakukan pemeriksaan.

\section{Hipotesis 2}

Hipotesis 2 dinyatakan bahwa variabel risiko audit (RISK) berpengaruh positif terhadap fee audit. Dari tabel 3 dapat dilihat bahwa nilai $t_{\text {hitung }}$ sebesar $-2,754$ dengan signifikansi alfa sebesar 0,007 <0,01 sehingga faktor risiko audit berpengaruh negatif terhadap fee audit ( $\mathrm{LnFee}$ ). Berdasarkan hasil tersebut maka Hipotesis 2 ditolak. Hal ini berarti bahwa semakin tinggi leverage, maka semakin rendah fee audit yang dibebankan auditor kepada klien. Hasil penelitian ini bertentangan dengan hasil penelitian Naser dan Nuseibeh (2007) serta Joshi dan Al-Bastaki (2000) yang menemukan pengaruh positif leverage terhadap fee audit.

Ketidakkonsistenan hasil penelitian ini dengan penelitian sebelumnya menunjukkan bahwa pada perusahaan dengan leverage tinggi di Jawa Timur mengindikasikan perusahaan berada dalam kondisi mendapat tekanan utang (financial distress) 
(Wondabio, 2006) sehingga kreditur akan cenderung memperketat pengawasan terhadap perusahaan sebagai dampaknya risiko audit bisa ditekan sehingga fee audit yang dibayarkan kepada auditor juga lebih rendah.

\section{Hipotesis 3}

Hipotesis 3 dinyatakan bahwa variabel waktu audit (TIME) berpengaruh positif terhadap fee audit. Dari tabel 3 dapat dilihat bahwa nilai $t_{\text {hitung }}$ sebesar -3,303 dengan signifikansi alfa sebesar 0,001 <0,01 sehingga faktor waktu audit berpengaruh negatif terhadap fee audit ( $\mathrm{LnFee}$ ). Berdasarkan hasil tersebut maka Hipotesis 3 ditolak. Hal ini berarti penugasan audit yang dilakukan pada periode busy season menetapkan fee audit yang lebih rendah dibandingkan fee audit pada periode non busy season. Hasil penelitian ini bertentangan dengan hasil penelitian Francis \& Wang (2005), Hay, et al. (2006), Griffint \& Lont (2007), serta Taylor (2011) yang menemukan pengaruh positif variabel waktu audit terhadap fee audit.

Ketidakkonsistenan hasil penelitian ini dengan penelitian sebelumnya kemungkinkan disebabkan bahwa auditor di KAP Jawa Timur sudah memprediksi banyaknya penugasan pada periode busy seasons, sehingga tidak terjadi kelebihan beban kerja pada periode tersebut (Naser dan Nuseibeh, 2007). Selain itu, auditor pada periode busy season menerima lebih banyak penugasan sehingga jumlah total fee yang diterima selama periode busy seasons tetap lebih besar dibandingkan fee pada periode non busy season. Dengan kata lain, auditor mengkompensasi penugasan audit yang lebih sedikit pada periode non busy season dengan meningkatkan fee audit. Selain itu, di Jawa Timur terdapat beberapa universitas negeri ternama yang mewajibakan mahasiswanya untuk melakukan praktek kerja lapangan di KAP, kegiatan ini sudah diantisipasi oleh beberapa KAP dengan mengikutsertakan mahasiswa magang dalam penugasan audit untuk periode busy season, misalnya untuk proses stock opname ataupun sampling audit sehingga mempercepat proses audit tanpa adanya tambahan fee yang cukup signifikan.

\section{Hipotesis 4}

Hipotesis 4 dinyatakan bahwa variabel pergantian KAP berpengaruh positif terhadap fee audit. Dari tabel 3 dapat dilihat bahwa nilai $\mathrm{t}_{\text {hitung }}$ sebesar 0,742 dengan signifikansi alfa sebesar 0,461 >0,01 sehingga faktor pergantian KAP tidak berpengaruh terhadap fee audit ( $\mathrm{LnFee})$. Berdasarkan hasil tersebut maka Hipotesis 4 ditolak. Artinya fee audit tidak ditentukan oleh ada atau tidak adanya pergantian KAP. Hasil penelitian ini berbeda dengan hasil penelitian yang dilakukan oleh Hoyle (1978) serta Raiborn dan Massoud (2006) yang berhasil menemukan pengaruh positif variabel pergantian KAP terhadap fee audit. Hal ini dikarenakan pada KAP di Jawa Timur, loyalitas klien terhadap KAP sangat besar sehingga klien cenderung mempertahankan hubungannya dengan KAP. Meskipun terdapat peraturan 
mengenai kewajiban pergantian KAP dan AP, dalam prakteknya beberapa KAP untuk klien yang sudah melebihi waktu perikatan hanya meminta tanda tangan AP yang lain atau AP memilihkan KAP yang lain yang masih merupakan koleganya untuk satu tahun audit dan tahun berikutnya kembali pada KAP yang sama.

\section{Hipotesis 5}

Hipotesis 5 dinyatakan bahwa variabel lokasi audit (LOCATION) berpengaruh positif terhadap fee audit. Dari tabel 3 dapat dilihat bahwa nilai t hitung sebesar 3,234 dengan signifikansi alfa sebesar 0,002 $<0,01$ sehingga faktor lokasi audit berpengaruh positif terhadap fee audit ( $\mathrm{LnFee}$ ). Hal ini berarti audit yang dilakukan di Jawa Timur menetapkan fee audit yang lebih tinggi dibandingkan daerah lain di luar Jawa Timur. Berdasarkan hasil tersebut maka Hipotesis 5 diterima. Hasil penelitian ini senada dengan penelitian yang dilakukan oleh Chan, et al. (1993) dan Peel \& Roberts (2003).

Berpengaruhnya lokasi audit terhadap fee audit dikarenakan tingkat kemudahan dalam mencapai lokasi audit mempermudah auditor dalam melakukan proses audit. Selain itu, Jawa Timur merupakan provinsi dengan tingkat pertumbuhan ekonomi yang paling tinggi di Indonesia (Sasongko, 2013), penyumbang perekonomian terbesar dalam sebuah negara menetapkan fee audit yang lebih tinggi dibandingkan dibandingkan daerah lain di negara tersebut (Taylor, 2011).

\section{Simpulan dan Saran}

Berdasarkan hasil penelitian yang telah dilakukan dapat diambil kesimpulan sebagai berikut: ukuran perusahaan dan lokasi audit berpengaruh positif terhadap fee audit, risiko audit dan waktu audit berpengaruh negatif terhadap fee audit, dan pergantian KAP tidak berpengaruh signifikan terhadap fee audit.

Terdapat sejumlah keterbatasan dalam penelitian ini yang dapat memberi arah bagi pengembangan selanjutnya. Penelitian ini dilakukan pada KAP di Jawa Timur untuk penugasan tahun 2012, oleh karena itu hasil penelitian ini tidak bisa digeneralisasi untuk wilayah selain Jawa Timur dan penugasan selain tahun 2012. Selain itu, nilai koefisien determinasi yang disesuaikan (adjusted $R^{2}$ ) yang cukup rendah menunjukkan bahwa masih banyak faktor lain yang belum dimasukkan dalam penelitian ini.

Saran untuk penelitian selanjutnya dengan memperhatikan keterbatasan-keterbatasan dalam penelitian ini, yaitu: peneliti selanjutnya diharapkan memperluas ruang lingkup penelitian hingga ke seluruh Indonesia agar dapat diperoleh gambaran lebih lengkap mengenai faktor-faktor yang berpengaruh terhadap fee audit. Peneliti selanjutnya dapat menambah variabel penelitian seperti fee selain jasa general audit dan harmonisasi SPAP dan IAS sehingga dihasilkan adjusted $R^{2}$ yang lebih besar. Fee selain jasa general audit dipilih karena dalam prakteknya auditor cenderung 
merendahkan fee audit dan menggantinya dengan perikatan selain jasa audit guna menutupi rendahnya fee audit. Harmonisasi SPAP dan IAS dipilih karena di beberapa negara adanya harmonisasi ini berpengaruh terhadap fee audit (Tuanakotta, 2013: 13).

\section{DAFTAR PUSTAKA}

, Keputusan Menteri Keuangan No. 17/PMK.01/2008 tentang “Jasa Akuntan Publik”. 2008. Available online at http://www.philipjusuf.com (Diakses pada 18 April 2013).

Besacier, N.G., dan Schatt, A. 2007. Determinants of Audit Fees For French Quoted Firms. Managerial Auditing Journal Vol. 22, No. 2, pp: 139-160. Available online at: www.emeraldinsight.com/0268-6902.htm

Bell, Timothy, B., Landsman, Wayne, R. 2000. Auditor's Perceived Business Risk and Audit Fees: Analysis and Evidence. Journal of Accounting Research; Vol. 39; Vol. 60, 4; ABI/INFORM Research; pg. 31.

Caneghem, T.V. 2010. Audit Pricing and The Big4 Fee Premium: Evidence From Belgium. Managerial Auditing Journal Vol. 25, No. 2, pp: 122-139. Available online at: www.emeraldinsight.com/0268-6902.htm

Chan, P., Ezzamiel, M., dan David, G. 1993. Determinants of Audit Fees For Quoted UK Companies. Journal of Business Finance and Accounting, Vol. 20, No. 6, pp: 765786.

Chung, D.Y., dan Lindsay, W.D. 1986. The Pricing of Audit Services: The Canadian Perspective. Contemporary Accounting Research, Vol. 5, pp:19-46.

Danim, S. 2007. Metode Penelitian Untuk Ilmu-ilmu Perilaku. Jakarta: Bumi Aksara.

Dechow, P., Sloan, R. 1991. ExecutiveIncentives and The Horizon Problem: an Empirical Investigation. Journal of Accounting and Economics, 14, 51-89.

Deis, Donald, R., Jr., \& Gary, A.G. 1992. Determinants of Audit Quality in the Public Sector, The Accounting Review, Vol 67, No.3.

Dhaliwal, D.S., C.A. Gleason, S., Heitzman, dan K.D. Melendrez. 2008. Auditor Fees and Cost of Debt. Journal of Accounting, Auditing \& Finance 23(1):1-22.

Elder, J., Randal, Beasley, Marks, S., dan Alvin, A.A. 2011. Jasa Audit dan Assurance Pendekatan Terpadu (Adaptasi Indonesia). Jakarta: Salemba Empat.

Ellis, Y., dan Booker, Q.L. 2011. Audit Fee Determinants in The Nonprofit Sector: A Study of Community Action Agencies. Journal of Finance and Accountancy Vol. 8. Available online at http://www.aabri.com/jfa.html

Fachriyah, N. 2008. Faktor-faktor yang Mempengaruhi Penentuan Fee Audit oleh Kantor Akuntan Publik di Malang. Tesis Program Magister Akuntansi Universitas Brawijaya Malang

Firth, M. 1985. An Analysis of Audit Fees and Their Determinants in New Zealand. Auditing: A Journal of Practice \& Theory Vol. 4, No.2, pp: 23-37

Francis, J., dan D. Wang. 2005. Impact of The SEC's Public Fee Disclosure Requirement on Subsequent Period Fees and Implication for Market Efficiency. Auditing: A Journal of Practice \& Theory 24, 45-160.

Ghozali, I. 2009. Aplikasi analisis multivariat dengan program SPSS. Semarang: Badan Penerbit Universitas Diponegoro. 
Griffin, Paul, A., dan Lont, D.H. 2007. An Analysis of Audit Fees Following The Passage of Sarbanes-Oxley. Asia-Pacific Journal of Accounting, Vol. 14, pp:161-192.

Hay, D., Knechel, dan Wong. 2006. "Audit Fees: A Meta-Analysis of The Effect of Supply and Demand Attributes. Contemporary Accounting Research 23, 141-191.

Harahap, S.S. 2002. Auditing Dalam Perspektif Islam. Jakarta: Pustaka Quantum.

Hoesada, J. 2009. Perbandingan antara SAK ETAP vs IFRS for SMEs. Makalah disajikan dalam Seminar Nasional Akuntansi : Seminar Tiga Pilar Akuntansi Indonesia. Malang, 17-18 Juli 2009.

Hoyle, J. 1978. Mandatory Auditor Rotation: The Arguments and Alternative. The Journal of Accountancy 145 (5):69-78

Ikatan Akuntan Indonesia. 2012. Standar Akuntansi Keuangan. Jakarta: Salemba Empat.

Institut Akuntan Publik Indonesia. 2011. Standar Profesional Akuntan Publik Indonesia Edisi 31 Maret 2011. Jakarta: Salemba Empat.

Institut Akuntan Publik Indonesia. 2011. Directory Kantor Akuntan Publik dan Akuntan Publik 2011. Jakarta: Kementerian Keuangan Republik Indonesia Sekretariat Jenderal Pusat Pembinaan Akuntan dan Jasa Penilai.

Jensen, M.C. 1986. Agency Cost of Free Cash Flow, Corporate Finance and Takovers. American Economic Review, 76, 323-329.

Joshi, P.L., dan H. Al-Bastaki. 2000. Determinants of Audit Fees: Evidence from the Companies Listed in Bahrain. International Journal of Auditing, Vol. 4, pp. 129-138.

Jubb, C.A., Hougton, K.A., dan S. Butterworth. 1996. Audit Fee Determinants: The Plural Nature of Risk. Managerial Auditing Journal Vol. 11, No. 3, pp: 25-40. Available online at: $\mathrm{http} / / \mathrm{dx}$. doi.org/10.1108/02686909610115222

Karim, A.K.M., dan Moizer, P. 1996. Determinants of Audit Fees In Bangladesh. International Journal of Accounting, Vol. 6, No. 5, pp 415-431.

La Porta, Rafael, Florencio Lopez-de Silanes, Andrei, S., dan Robert, W.V. 2000. Agency Problems and Dividend Policies around The World. Journal of Finance, 55 (1), 1-33.

Ludigdo, U. 2005. Pemahaman Strukturasi atas Praktik Etika di Sebuah Kantor Akuntan Publik. Disertasi Program Doktor Studi Ilmu Ekonomi Kekhususan Manajemen Universitas Brawijaya Malang.

Maradona, A.F. 2009. Tenur Audit dan Kualitas Audit: Suatu Pembuktian Bagi Kewajiban Rotasi Auditor di Indonesia. Tesis Program Magister Akuntansi Universitas Brawijaya Malang.

Naser, K., dan Nuseibeh, R. 2007. Determinants of Audit Fees: Empirical Evidence From an Emerging Economy. International Journal of Commerce and Economy, Vol. 17, No. 3, pp: 239-254. Available online at: $\underline{w w w . e m e r a l d i n s i g h t . c o m / 1056.9219 . h t m ~}$

Online, Akuntan. 2013. Florus, Harus Ada Standarisasi Fee Audit. Available online at: http://akuntanonline.com/showdetail.php? $\bmod =$ art \& id $=475 \& \mathrm{t}=$ Florus, \% 20 Harus \%20Ada\%20Standarisasi\%20Fee\%20Audit\%20\&kat=Organisasi

Pong, C.M., dan Whittington, G. 1994. The Determinants of Audit Fees: Some Empirical Models. Journal of Business Finance and Accounting, Vol. 21, No. 8, pp. 1071-1095

Raiborn, C., C.A. Schorg, dan M. Massoud. 2006. Should Auditor Rotation Be Mandatory? Journal of Corporate Accounting and Finance 17 (4):37-49. 
Sasongko, B.A. 2013. Jawa Timur Alami Pertumbuhan Ekonomi Terbaik. Available online at: http://www.solopos.com/2013/03/08/jawa-timur-alami-pertumbuhan-ekonomiterbaik-386061

Sekaran, U., dan Bougie, R. 2010. Research Methods for Business-A Skill Building Approach. USA: John Wiley \& sons, Inc.

Shafie, R.B. 2003. The Determinants of Audit Fees: The Case of The Banking Industry In Malaysia. Tesis Program Master of Science (International Accounting) Universiti Utara Malaysia.

Simunic, D.A. 1980. The Pricing Of Audit Services: Theory and Evidence. Journal of Accounting Research Vol. 18, No. 1: pp 161-190.

Stanley, Jonathan, D. 2011. Is the Audit Fee Disclosure a Leading Indicator of Clients' Business Risk?. Auditing: A Journal of Practice \& Theory Vol. 30, No. 3: pp 157179.

Tarigan, R. 2012. Ekonomi Regional Teori dan Aplikasi. Jakarta: Bumi Aksara.

Taylor, Mark, H., dan Simon, D.T. 1999. Determinants of Audit Fees: The Importance of Litigation, Disclosure, and Regulatory Burdens in Audit Engagement in 20 Countries. The International Journal of Accounting Vol. 34, No.3, pp: 375-388.

Taylor, S.D. 2011. Does Audit Fee Homogeneity Exist? Premiums and Discount Attributable to Individual Partners. Auditing: A Journal of Practice and Theory Vol 30, No. 4, pp: 249-272.

Wijaya, A.L., Bandi, dan Sri, H. 2010. Pengaruh Kualitas Akrual dan Leverage Terhadap Cash Holding Perusahaan. Jurnal Akuntansi dan Keuangan Indonesia, 7(2), 170 186.

Wondabio, L.S. 2006. Evaluasi Manajemen Risiko Kantor Akuntan Publik (Kap) dalam Keputusan Penerimaan Klien (Client Acceptance Decisions) Berdasarkan Pertimbangan dari Risiko Klien (Client Risk), Risiko Audit (Audit Risk) Dan Risiko Bisnis Kap (Auditor's Business Risk). Simposium Nasional Akuntansi IX. Padang. 